
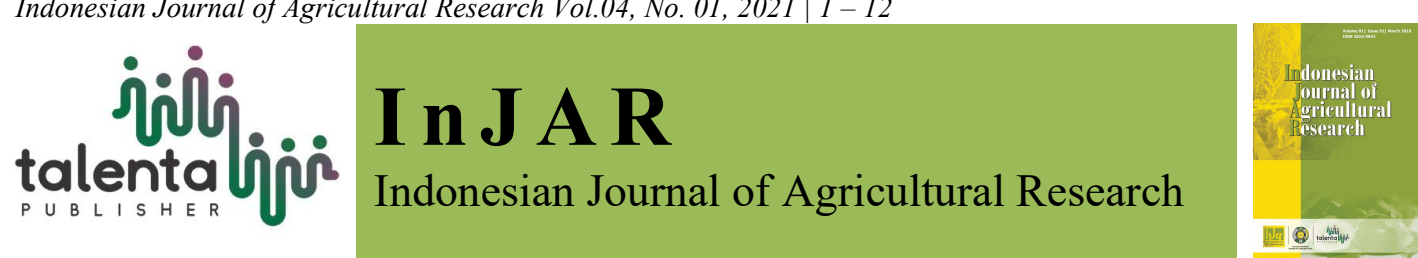

\title{
Factors Determining Choice of Conventional Labour Among Yam Producers in Benue State of Nigeria
}

\author{
M. S. Sadiq ${ }^{1 \& 2}$, I. P. Singh' ${ }^{2}$ M. M. Ahmad , and A. Garba $^{1}$ \\ ${ }^{I}$ Department of Agricultural Economics and Extension, FUD, Dutse, Nigeria \\ ${ }^{2}$ Department of Agricultural Economics, SKRAU, Bikaner, India \\ ${ }^{3}$ Department of Agricultural Economics, BUK, Kano, Nigeria
}

\begin{abstract}
The present research empirically determined the factors that influenced the choice of combined labour for efficient yam marketable surplus in Benue State of Nigeria. 2016 cropping season cross-sectional data elicited by structured questionnaire complemented with interview schedule from a total of 120 farmers chosen through a multistage sampling technique was used. The instruments used for data analysis were descriptive and inferential statistics. The empirical evidences showed that decision for choice of efficiently combined labour that is supplemented by paid labour for efficient yam marketable surplus was affected by low yam productivity and low income which largely owed to poor proceeds from product marketing. Gender stereotype due to culture and religious barriers affected women access and control to productive access, thus hinders women active involved in yam entrepreneurship as they cannot carter for paid labour. Thus, it can be inferred that utilization of combined labour was affected by poor yield, gender stereotype and poor economic capital. Therefore, for farmers to be able to harness combined labour efficiently for a good marketable surplus, thus a better wellbeing for farmers, farmers need technical guided on potential yield; provision of buffer stocks for a remunerative price normalization; and, breaking the jinx of gender inequality through tacit sensitization in the studied area.
\end{abstract}

Keywords: Benue State, choice, farmers, labour, Nigeria, yam

\section{Introduction}

Agricultural production in Nigeria is labor intensive in comparison to the developed world, with more than $90 \%$ of the population being small-scale farmers who farm less than two hectares and depend on unpaid labor as a major source of agricultural labor [1]. One of the root causes of past agricultural development programs launched by successive Nigerian governments' failures is our inability to effectively and efficiently develop and use the country's manpower resources, especially in the rural sector [2].

\footnotetext{
*Corresponding author at: Department of Agricultural Economics and Extension, FUD, P.M.B. 7156, Dutse, Nigeria

E-mail address: sadiqsanusi30@gmail.com
} 
It is critical to make efficient use of the fundamental factors of development, such as labor, land, and capital, in order to achieve long-term agricultural growth [3] [4]. Human labor stimulates other development factors and converts required outputs into farm inputs. Human labor is the only significant source of labor available to small-holder yam farmers in Nigeria [4].

Planting precision, increased weed control, timely harvesting, and crop processing have all suffered as a result of the labor shortage [4] [5] [6]. Several factors, including the decreasing share of family labor, enterprise type and nature, the age at which children are considered potential labor, farm size, and rural-urban drift, have limited the supply and use of this labor, resulting in a labor shortage and rising labor wage rates in the farm sector [2].

Farm labor supply research has shown that total labor supply is dependent on variables such as population size, age distribution, and some institutional factors, according to [4]. Hired labor accounted for $88.0 \%$ of total farm labor use, according to [4] [6] [7], highlighting its importance in agricultural activities. Other types of labor that may be used include family labor and exchange labor.

The supply of labor for agricultural production in the region has recently decreased dramatically. This is due to a variety of factors, including rural-urban migration, increased school attendance; increased work opportunities associated with industrialization, urbanization, and increased off-farm employment, among others. Because of the increased participation of labor in off-farm activities, there is concern that agricultural growth and development will be delayed, and any effort to reduce hunger and achieve self-sufficiency by 2050 will be a mirage, resulting in a shortage of farm labor and rising labor wage rates. The choice of labor for crop production is influenced by a variety of socioeconomic factors. As a result, in order to assess the degree of impact, awareness of such variables is also needed.

Thus, in view of the foregoing, the need to identifying the idiosyncratic factors that influenced the choice of farm labour among yam farmers in Nigeria's Benue State was conceptualized as literature showed no evidence of related research in the studied area. However, the only related research focused on cassava farmers and it was conducted in Akwa-Ibom State of Nigeria. The specific objectives of the study were to describe the socio-economic characteristics of the respondents; determine the factors that influenced exclusive choice of family or hired labours; and, factors that influenced mutual choice of family and hired labours.

Hypotheses:

$\mathrm{H}_{0}$ : There is no significant relationship between family and hired labours.

$\mathrm{H}_{1}$ : There is significant correlation between the family and hired labours. 


\section{Research Methodology}

The study area is located in Nigeria's north central region, with a population of 4,780,389 people [8]. The state's coordinates are latitude $625 \mathrm{~N}$ and $808 \mathrm{~N}$, as well as longitude $747 \mathrm{E}$ and $100 \mathrm{E}$ Greenwich meridian. The state's landmass is projected to be 5.09 million hectares, including 3.8 million hectares of arable land. The state has a tropical climate, with an average annual rainfall of $1723 \mathrm{~mm}$ and a temperature of $27.2^{\circ} \mathrm{C}$. Agriculture is the main occupation of the natives, with more than $70 \%$ of the population engaged in arable crop farming, while others work in fishing, cloth weaving, white collar work, businesses, arts and crafts, and Ayurvedic medicine, among other things.

The cross-sectional data was collected from 120 active yam farmers using a multi-stage sampling design. Given that yam is grown in all of Benue's agricultural zones, the first stage involved a convenient range of Otukpo Local Government Area in Benue State. The second stage involved selecting four (4) villages at random, namely Upu-Entekpa, Otada, Okpanehe, and Ogodumu. The final stage included selecting thirty (30) active yam producers at random from each of the villages, for a total sample size of one hundred and twenty (120) farmers.

A well-structured questionnaire complemented with an interview schedule was the instrument used for data collection. The questionnaire's content validity was pre-tested with 20 farmers in a pilot survey, and the reliability test resulted in a Cronbach' Alpha coefficient higher than the 0.60 cut-off suggested by [9] as suitable for exploratory testing. As a result, the approximate value reflects the accuracy and stability with which the questionnaire tests the definition and aids in determining the measure's usefulness. With the aid of block extension agents, ex-post data of 2016 yam cropping season were collected during 2016/2017. Objective I, II and III were achieved using descriptive statistics, bivariate probit and multinomial logit regression models respectively.

\subsection{Model Specification: Bivariate probit model}

The following is a bivariate probit model that takes into account the probability of contemporaneous association in the decisions of family and hired labors for efficiency management:

$$
Y_{i j}=X_{i j} \beta_{j}+\varepsilon_{i j}
$$

Where $Y_{i j}(j=1, \ldots, m)$ represent the choice of a labour type $(m=2)$ faced by the $i^{\text {th }}$ farmer $(i=$ $1, \ldots, n), X_{i j}$ is a $1^{*} \mathrm{k}$ vector of observed variables that influence the choice of a labour type. $\beta_{\mathrm{j}}$ is a $\mathrm{k}^{*} 1$ vector of unknown parameters to be estimated and $\varepsilon_{\mathrm{ij}}$ is the stochastic term. In this specification, each $Y_{j}$ is a binary variable, thus equation 1 is actually a system of $m$ equations to be estimated: 


$$
\begin{aligned}
& \mathrm{Y}_{1}^{*}=\alpha_{1}+\mathrm{X} \beta_{1}+\varepsilon_{1} \\
& \mathrm{Y}_{2}^{*}=\alpha_{2}+\mathrm{X} \beta_{2}+\varepsilon_{2}
\end{aligned}
$$

Where $Y_{1}^{*}$ and $Y_{2}^{*}$ are two latent variables underlying each decision of labour type, that $Y_{j}=1$, if $Y_{j}>0$; otherwise $0 . Y_{1}^{*}$ and $Y_{2}^{*}$ are family and hired labour, respectively. The $\varepsilon_{i j}$ of likely will experience a stochastic dependence. This dependence among the elements can be considered by assuming $\varepsilon_{i j}$ that is multivariate normally distributed [10]. Thus, in the bivariate probit model the stochastic term are assumed to have multivariate normal distributions with mean equal to zero.

\subsection{Model Specification: Multinomial logit model}

In this case, the choice set is the possible combinations of labour type for efficient management and below is the specified model:

$$
\begin{aligned}
& Y_{i}^{*}=\alpha+X \beta+\varepsilon_{i} \\
& Y_{i}^{*}=\alpha+X_{1} \beta_{1}+X_{2} \beta_{2}+X_{3} \beta_{3}+X_{4} \beta_{4}+X_{5} \beta_{5}+\cdots+X_{n} \beta_{n}+\varepsilon_{i}
\end{aligned}
$$

where: $\mathrm{Y}_{\mathrm{i}}{ }^{*}=$ represents choice of labour $(1=$ family labour, $2=$ hired labour, $3=$ combine labour). Combine labour encompasses family and hired labour. $\mathrm{X}_{1}=$ Profit (Naira); $\mathrm{X}_{2}=$ Total factor productivity (index); $\mathrm{X}_{3}=$ Gender $($ male $=1$, otherwise $=0) ; \mathrm{X}_{4}=$ Age (years); $\mathrm{X}_{5}=$ Marital status (married $=1$, otherwise $=0$ ); $\mathrm{X}_{6}=$ Education (years); $\mathrm{X}_{7}=$ Household size (number); $\mathrm{X}_{8}=$ Experience (year); $\mathrm{X}_{9}=$ Operational holding (hectare); $\mathrm{X}_{10}=$ Farm acquisition (owned $=1$, otherwise $=0$ ); $X_{11}=$ Seed variety (improved $=1$, local $=0$ ); $X_{12}=$ Non-farm income (yes $=1$, otherwise $=0$ ); $X_{13}=$ Co-operative membership (yes $=1$, otherwise $=0$ ); $X_{14}=$ Credit access (yes $=1$, otherwise $=0$ ); $X_{15}=$ Extension visit (number); $X_{16}=$ Income (in Naira); $\mathrm{X}_{17}=$ Yield $(\mathrm{kg}) ; \beta_{0}=$ Intercept; $\beta_{1-n}=$ Vector of parameters to be estimated; and, $\varepsilon_{\mathrm{i}}=$ Stochastic term.

\section{Results and Discussion}

\subsection{Socio-Economic Profiles of Yam Farmers}

A perusal of Table 1 depicted an active, economic and productive yam farming population as evident from the mean age of 50 years $(\mathrm{SD} \pm 13.44)$. The implication of having an economically viable farming population would lead to a sustainable increase in yam production in the study area. This age category is expected to be more responsive to new agricultural technologies. This is similar to the findings of [11] in Abuja, Nigeria, on socioeconomic factors affecting yam development. The findings, however, contradict those of [12], who studied the economics of yam development in south-eastern Nigeria. The enterprise is dominated by male farmers $(68.3 \%)$ and this is largely connected to gender stereotype due to culture which hinders women 
access and control to productive resources and not the characterized laborious nature of yam production which was alleged by literatures. This result is consistent with the findings [12] on yam development in South Eastern Nigeria. People with family responsibility i.e. married men dominated $(77.5 \%)$ yam enterprise, thus suggesting a marketable surplus-led yam production in the studied. The rate of literacy among the farmers is high $(85.8 \%)$, thus implying a farming population that will be receptive to yam technologies for enhanced productivity. Education serves as a vehicle or catalyst that accelerates the rate of adoption and diffusion of farm innovations-technologies. This finding is consistent with the findings of [13], who studied the socioeconomic characteristics of rural farmers in Lagos, Nigeria. Most of the farmers maintained large household (average of 9 persons), thus an asset if composed of able-bodied people viz. access to free labour, otherwise a liability if the dependency ratio is high. A large household composed of able-bodied people will provide a farmer with free labour which is virile, given the intensive nature of yam production. Likewise, a large household characterized by high independency ratio stands the chance of utilizing proceeds to finance hired labour for high yam productivity. However, large household composed of weaker people is a liability as household head stands to contend with excessive consumption expenditure. The mean year of experience been 21 years suggests that most of the farmers had the requisite experience for managerial efficiency in yam production. Both the average household size composition and experience contradicted the results of [2] in their research on cassava farmers' labor option decisions in Nigeria's Akwa-Ibom province. Inheritance been the predominant (70\%) source of land acquisition suggests the tendency of large scale, cash crop cultivation and mechanized farming to be unlikely due to susceptibility of farm lands to fragmentation, thus a threat to yam food security due to poor productivity. As household size increases there will be more pressure on land as every adult member of the family would want to have a share of the land. The extinct of extension services delivery suggests the likelihood of innovative yam technologies been beyond the reach of the farmers. This has a far-reaching consequence on yam food security as the farmers are inundated with old farm practices. There is poor utilization of social capital due to poor participation of farmers in social organization (12.5\%), thus suggesting that most of the farmers had no access to pecuniary advantages viz. input bulk discount, output marketing bargaining power and credit access either in cash or kind. Most of the farmers are faced with capital constrain required for efficient resource mix as evidenced by lack of access to credit among most of them (0.8\%). Most of the farmers (64.2\%) are into enterprise diversification viz. participation in non-farm activities as a risk coping mechanism. Despite poor access to extension service delivery, most $(80.8 \%)$ of the farmers used improved variety, thus indicating globalization of a farming population with market-led dimension. However, preference for improved variety may be connected with past experiences. Mean farm size of 2.37 showed a pre-entrepreneurial farming population with a greater opportunity to produce beyond just mere survival. At this level, the farmers are not entrepreneur in true sense neither are they truly market-oriented. This result is in line with the argument of [4] that small-scale farmers dominate 
agriculture in yam production of Nigeria's Abia state. The mean agricultural holding of 7.06 hectares imply that most of the farmers had large agricultural holdings but cultivate yam on small-scale, thus suggesting that most of the farmers engaged in farm diversification as a coping strategy against risk and uncertainty. A combined labour viz. family and hired labour is the most commonly kind of labour used in yam production. This may be connected to unavoidable absence of farm family members either due to school, gainful employment and rigorous energetic task that characterized yam operations.

Table 1. Socio-Economic Profiles of the Yam Farmers

\begin{tabular}{|c|c|c|c|c|}
\hline Variables & Frequency & Percentage & $\mathrm{X} \pm \mathrm{SD}$ & $\chi^{2}$ test statistic \\
\hline \multicolumn{5}{|c|}{ Age } \\
\hline$\leq 29$ & 9 & 7.5 & & \multirow{6}{*}{$24.92 * * *$} \\
\hline $30-39$ & 14 & 11.7 & & \\
\hline $40-49$ & 37 & 30.8 & & \\
\hline $50-59$ & 34 & 28.3 & & \\
\hline$\geq 60$ & 26 & 21.7 & & \\
\hline Total & 120 & 100 & $50 \pm 13.44$ & \\
\hline \multicolumn{5}{|c|}{ Gender } \\
\hline Male & 82 & 68.3 & & \multirow{3}{*}{$16.13 * * *$} \\
\hline Female & 38 & 31.7 & & \\
\hline Total & 120 & 100 & & \\
\hline \multicolumn{5}{|c|}{ Marital status } \\
\hline Married & 93 & 77.5 & & \multirow{4}{*}{$105.95 * * *$} \\
\hline Single & 10 & 8.3 & & \\
\hline Widower & 17 & 14.2 & & \\
\hline Total & 120 & 100 & & \\
\hline \multicolumn{5}{|c|}{ Educational level } \\
\hline Informal & 17 & 14.2 & & \multirow{5}{*}{$13.27 * * *$} \\
\hline Primary & 42 & 20.0 & & \\
\hline Secondary & 37 & 35.0 & & \\
\hline Tertiary & 17 & 30.8 & & \\
\hline Total & 120 & 100 & & \\
\hline \multicolumn{5}{|c|}{ Household size } \\
\hline$\leq 3$ & 2 & 1.7 & & \multirow{5}{*}{$53.00 * * *$} \\
\hline $4-6$ & 23 & 19.2 & & \\
\hline $7-9$ & 56 & 46.7 & & \\
\hline$\geq 10$ & 39 & 32.5 & & \\
\hline Total & 120 & 100 & $9 \pm 4.18$ & \\
\hline \multicolumn{5}{|c|}{ Farming experience } \\
\hline$\leq 3$ & 10 & 8.3 & & \multirow{5}{*}{$166.20 * * *$} \\
\hline $4-6$ & 13 & 10.8 & & \\
\hline $7-9$ & 6 & 5.0 & & \\
\hline$\geq 10$ & 91 & 75.8 & & \\
\hline Total & 120 & 100 & $21 \pm 14.01$ & \\
\hline \multicolumn{5}{|c|}{ Land acquisition } \\
\hline Inheritance & 84 & 70.0 & & \multirow{7}{*}{$606.00 * * *$} \\
\hline Purchase & 1 & 0.8 & & \\
\hline Borrowed & 3 & 2.5 & & \\
\hline Rent & 2 & 1.7 & & \\
\hline Communal land & 1 & 0.8 & & \\
\hline Multiple source & 29 & 24.2 & & \\
\hline Total & 120 & 100 & & \\
\hline \multicolumn{5}{|c|}{ Extension contact } \\
\hline Yes & - & - & & \\
\hline No & 120 & 100 & & - \\
\hline Total & 120 & 100 & & \\
\hline
\end{tabular}


Table 1. Continued

\begin{tabular}{|c|c|c|c|c|}
\hline Variables & Frequency & Percentage & $\mathrm{X} \pm \mathrm{SD}$ & $\chi^{2}$ test statistic \\
\hline \multicolumn{5}{|c|}{ Co-operative membership } \\
\hline Yes & 15 & 12.5 & & $67.50 * * *$ \\
\hline No & 105 & 87.5 & & \\
\hline Total & 120 & 100 & & \\
\hline \multicolumn{5}{|c|}{ Access to credit } \\
\hline Yes & 1 & 0.8 & & $116.03 * * *$ \\
\hline No & 119 & 99.2 & & \\
\hline Total & 120 & 100 & & \\
\hline \multicolumn{5}{|c|}{ Non-farm activities } \\
\hline Yes & 77 & 64.2 & & $9.63 * * *$ \\
\hline No & 43 & 35.8 & & \\
\hline Total & 120 & 100 & & \\
\hline \multicolumn{5}{|c|}{ Yam sett variety } \\
\hline Hybrid & - & - & & $45.63 * * *$ \\
\hline Improved & 97 & 80.8 & & \\
\hline Local & 23 & 19.2 & & \\
\hline Total & 120 & 100 & & \\
\hline \multicolumn{5}{|c|}{ Agricultural holding } \\
\hline Small scale $(<2)$ & 4 & 3.3 & & $82.40 * * *$ \\
\hline Medium scale $(<4)$ & 32 & 26.7 & & \\
\hline Large scale $(\geq 4)$ & 84 & 70.0 & & \\
\hline Total & 120 & 100 & $7.06 \pm 5.53$ & \\
\hline \multicolumn{5}{|c|}{ Operational holding } \\
\hline Small scale $(<2)$ & 49 & 40.8 & & $12.15 * * *$ \\
\hline Medium scale $(<4)$ & 49 & 40.8 & & \\
\hline Large scale $(\geq 4)$ & 22 & 18.3 & & \\
\hline Total & 120 & 100 & $2.37 \pm 1.82$ & \\
\hline \multicolumn{5}{|c|}{ Labour source } \\
\hline Family labour & 22 & 18.3 & & $132.75 * * *$ \\
\hline Hired labour & 19 & 15.8 & & \\
\hline Family and hired labour & 72 & 60.0 & & \\
\hline Family and communal & 6 & 5.0 & & \\
\hline Hired and communal & 1 & 0.8 & & \\
\hline Total & 120 & 100 & & \\
\hline
\end{tabular}

Source: Field survey, 2017

\subsection{Factors Determining Choice of Family and Hired Labours}

The significance of the Wald $\mathrm{Chi}^{2}$ test statistic at $1 \%$ probability level indicated that the bivariate probit model best fit the specified equation and the parameter estimates included in the model are different from zero at 10\% degree of freedom (Table 2). Therefore, it can be inferred that the chosen model is reliable for future prediction with efficiency, certainty and consistency. Besides, the $\mathrm{LR} \mathrm{Chi}{ }^{2}$ test statistic being within the plausible margin of $10 \%$ implies that the response variables are dependent i.e. correlated. Sequel to this the null hypothesis is rejected in favour of alternative hypothesis. Thus, it can be inferred that the decision to use one labor type will also lead to the use of the alternative.

A cursory review of the results showed total factor productivity (TFP), household size and yield to be the common variables that influenced both the decision to use family and hired labours exclusively as evidenced by their respective estimated coefficients which were within the plausible margin of $10 \%$ probability level. The variables that exclusively influenced the decision to employ family and hired labour were education and income; and, age, gender, 
operational holdings, seed variety and non-farm income respectively, as indicated by their respective parameter estimates which were within the acceptable margin of $10 \%$ significant level.

The negative significance of TFP implied that farmers with high TFP neither use family nor hired labours exclusively but rather both labour types were mutually employed in yam production. Poor labour productivity of family labour owing to limitation in harnessing it efficiently as it is offered free and the need to minimize incurred cost on paid labour, thus affected the exclusive use of neither family labour nor hired labour. Thus, for a unit increase in TFP, the chance of not using family and hired labours exclusively would be 3.62 and $10.63 \%$ respectively.

The significant of the household size coefficient depicts that large household with less value for western education employed family labour which is free; while large household with high priority for education used paid labour due to unavoidable absence of children who are in school during the farm work. Also, household composed of able-bodied men, engaged in income earning activities, is likely to resort to hired labour for its farm operation. Therefore, a unit increase in a household will increase the chances of a farm family with less educational priority to use family labour by $0.17 \%$ and less likely to use hired labour by $0.52 \%$.

The positive significant of the yield coefficient revealed that high yam productivity encouraged small-scale farmers to opt for family labour as it is free with little or no cost associated. Likewise, high productivity which translates to high income turnover, ceteris paribus, encouraged enterprise farmers to exploit paid labour for high labour productivity, thus yielding high yam marketable surplus. Thus, the chances of using family and hired labours exclusively for a unit increase in yield would be 0.005 and $0.012 \%$ respectively. In the same vein, the probability of using family labour for a unit increase in income will be $0.59 \%$.

The negative significant of the education coefficient showed that educated farmers are less likely to use family labour exclusively as they are entrepreneurship-focused on yam production. Also, been literate, they would not compromise their family members' education for farm work, as school will make their children unavoidable absent for farm operations. Therefore, the probability of educated farmers not employing family labour for a unit increase in educational level will be $0.14 \%$. [2] reported that higher educational attainment positively influenced the use of hired labour.

The positive significant of age coefficient implied that because aged farmers are not energetic enough to undertake numerous difficult tasks involved in yam production dueto tediousness and high energy requirement, they opted for hired labour. Also, the use of hired labour is more common among aged headed households as they have large operational holdings. Thus, the 
chance of using hired labour for a unit increase in age will be $0.082 \%$. This finding is in tandem with the finding of [2] who discovered preference for hired labour among aged farmers.

Lack of access and control to productive resources due to gender stereotype affected women farmers to use hired labour as indicated by the negative significant of gender coefficient. Thus, gender inequality has made women farmers to operate on marginal farm, thereby making household physical energy the only accessible labour for their yam production. Therefore, the probability of woman farmer not using hired labour will be $1.13 \%$.

The positive significant of operational holding coefficient revealed that large scale farmers used hired labour in their yam production given that the scale of production targets the markets and not only or majorly household food security which is common among smallholder farmers. Thus, the probability of employing hired labour for a unit increase in farm size will be $1.19 \%$. Similar finding was observed by [2] in their studied area. The positive significant of the seed variety coefficient implied that farmers that adopted improved variety used hired labour for their yam production so as to maximize labour productivity in order to achieve potential yield which is indispensable to the off-set of incurred farm cost. Thus, the possibility of farmers who adopted improved seed variety to employ hired labour will be $1.36 \%$. The positive significant of the non-farm income coefficient revealed that farmers with stream of incomes other than onfarm income produced yam majorly for household food security, thus used hired labour due to labour-shift to non-farm business. Therefore, the probability of earning non-farm income will increase the chances of employing hired labour by $2.01 \%$.

Table 2. Bivariate Probit Regression for Choice of Family and Hired Labours

\begin{tabular}{lrrrr}
\hline \multirow{2}{*}{\multicolumn{1}{c}{ Variable }} & \multicolumn{2}{c}{ Family labour } & \multicolumn{2}{c}{ Hired labour } \\
\cline { 2 - 5 } & \multicolumn{1}{c}{ Coefficient } & t-stat & \multicolumn{1}{c}{ Coefficient } & \multicolumn{1}{c}{ t-stat } \\
\hline Intercept & $-7.3915(3.7444)$ & $1.974^{* *}$ & $-10.094(6.6935)$ & $1.508^{\mathrm{NS}}$ \\
Profit & $3.45 \mathrm{e}-7(1.19 \mathrm{e}-6)$ & $0.289^{\mathrm{NS}}$ & $1.62 \mathrm{e}-6(1.73 \mathrm{e}-6)$ & $0.936^{\mathrm{NS}}$ \\
TFP & $-3.6171(0.9905)$ & $3.652^{* * *}$ & $-10.633(1.8237)$ & $5.830^{* * *}$ \\
Age & $-0.0370(0.0272)$ & $1.359^{\mathrm{NS}}$ & $0.0816(0.0431)$ & $1.894^{*}$ \\
Gender & $0.4219(0.4098)$ & $1.029^{\mathrm{NS}}$ & $-1.1292(0.5802)$ & $1.946^{*}$ \\
Marital status & $-0.3705(0.4210)$ & $0.880^{\mathrm{NS}}$ & $-0.7483(0.5468)$ & $1.368^{\mathrm{NS}}$ \\
Education & $-0.1379(0.0492)$ & $2.803^{* * *}$ & $0.0905(0.0840)$ & $1.076^{\mathrm{NS}}$ \\
Household size & $0.1742(0.0679)$ & $2.565^{* *}$ & $-0.5209(0.1433)$ & $3.633^{* * *}$ \\
Experience & $-0.0202(0.0245)$ & $0.824^{\mathrm{NS}}$ & $-0.0266(0.0274)$ & $0.969^{\mathrm{NS}}$ \\
Operational holding & $0.1035(0.2694)$ & $0.384^{\mathrm{NS}}$ & $1.1940(0.4394)$ & $2.717^{* * *}$ \\
Farm acquisition & $0.1621(0.4444)$ & $0.364^{\mathrm{NS}}$ & $-0.5847(0.6094)$ & $0.959^{\mathrm{NS}}$ \\
Seed variety & $1.1941(0.7747)$ & $1.541^{\mathrm{NS}}$ & $1.3600(0.8160)$ & $1.667^{*}$ \\
Non-farm income & $-0.4940(0.5198)$ & $0.950^{\mathrm{NS}}$ & $2.0120(0.9147)$ & $2.200^{* *}$ \\
Co-op. membership & $-0.0624(0.6382)$ & $0.097^{\mathrm{NS}}$ & $0.0621(0.7336)$ & $0.084^{\mathrm{NS}}$ \\
Credit access & $0.1183(0.4993)$ & $0.237^{\mathrm{NS}}$ & $-0.0361(0.5097)$ & $0.070^{\mathrm{NS}}$ \\
Extension visit & $0.1435(0.4203)$ & $0.341^{\mathrm{NS}}$ & $-0.5402(0.5755)$ & $0.938^{\mathrm{NS}}$ \\
Annual income & $0.5940(0.2744)$ & $2.165^{* *}$ & $0.4708(0.4382)$ & $1.074^{\mathrm{NS}}$ \\
Yield & $0.0053(0.0017)$ & $3.153^{* * *}$ & $0.0117(0.0031)$ & $3.703^{* * *}$ \\
\hline Wald Chi ${ }^{2}$ & & & & $\mathbf{5 6 . 1 9}[\mathbf{0 . 0 0 9 7}]^{* * *}$ \\
\hline LR Chi ${ }^{2}$ & & & $\mathbf{1 2 . 2 6 [ 0 . 0 0 0 4}]^{* * *}$ \\
\hline Source Field & &
\end{tabular}

Source: Field survey, 2017

Note: $* * * * * * \&^{\mathrm{NS}}$ imply significant at $1 \%, 5 \%, 10 \% \&$ non-significant, respectively.

Figures in ( ) and [ ] are standard error and probability level, respectively 


\subsection{Factors Determining Choice of Combined Labour}

Owing to the prove of dependence between family and hired labours as evidenced by the significance of LR $\mathrm{Chi}^{2}$ statistic of Bivariate probit model, the multinomial logit regression was applied to determine the factors that influenced the choice of combined labours viz. family and hired labours. A perusal of Table 3 showed multinomial probit regression model to be fit for the specified equation as indicated by the $\mathrm{LR} \mathrm{Chi}^{2}$ test statistic which is within the plausible margin of $10 \%$ degree of freedom. In addition, the significance of the $\mathrm{LR} \mathrm{Chi}^{2}$ test statistic implies that the estimated coefficients in the model are different from zero at $10 \%$ probability level. The empirical evidence showed absence of multicollinearity as indicated by the variance inflation factors of the explanatory variables which were within the acceptable margin of 10.0. Thus, with the foregoing proves, it can be inferred that the estimated parameters of the chosen model are reliable for prediction with accuracy and efficiency.

A cursory review of the results showed that choice of combined labour was influenced by TFP, education, household size, operational holding, yield and annual income. The positive significant of the TFP implied that farmers that achieved high TFP in resource allocation opted for combined labour so as to maintain optimum farm efficiency that translates into high income turnover ratio. Thus, the likelihood of using combined labour for a unit increase in TFP will be $12.67 \%$.

Apart from the entrepreneurship-focus, most of the highly educated farmers are gainfully employed in non-farm activities, so they are less likely to have time for farm activities, thus used combined labour to rationalize cost and maximize output as indicated by the positive significant of the education coefficient. In the same vein, poor labour productivity of family labour owing to limitation in harnessing it efficiently as it is offered free and the need to avoid high cost on paid labour, thus affecting farm optimization, made farmers to supplement the ablebodied family labour with cost efficient paid labour rather than exclusive use of one particular kind of labour in yam production. Therefore, the likelihood of employing combined labour for a unit increase in educational level will be $0.29 \%$

The negative significant of the household size coefficient showed that large household composed of members who are out of school i.e. have less priority for education didn't opt for combined labour as it is not cost-wise efficient but rather they relied exclusively on family labour which is free and in abundance. Thus, the probability of not using combined labour for a unit increase in household size will be $0.34 \%$. The negative significant of the operational holdings implied that farmers with small operational holdings didn't opt for combined labour. This may be attributed to diseconomies of scale and such farmers produced mainly for household consumption so as to cope with household food security and not for market. In another vein, farmers with large operational holdings but faced with diseconomies are likely to rely on free labour viz. family and borrowed labours so as to cut-cost rather than supplementing 
family labour with hired labour. Thus, the probability of not using combined labour for a unit increase in operational holding will be $0.94 \%$. Likewise, the probability of small-holder farmers not choosing combined labour will be $0.94 \%$.

The negative significant of yield coefficient revealed that farmers with low yield would not prefer combined labour as it amount to cost inefficient to supplement free labour with paid labour. Thus, the probability of farmers with low yield not employing combined labour will be $0.021 \%$. The negative significant of annual income coefficient showed that farmers with low income would not prefer combined labour as they relied on social capital because they lack economic capital to improvise for paid labour as a supplement. Therefore, the probability of farmers not using combined labour if income is low will be $1.29 \%$.

Table 3. Multinomial Logit Regression for Hired and Combined Labours

\begin{tabular}{|c|c|c|c|c|c|}
\hline \multirow{2}{*}{ Variable } & \multicolumn{2}{|c|}{ Hired labour } & \multicolumn{2}{|c|}{ Combined labour } & \multirow[t]{2}{*}{ VIF } \\
\hline & Coefficient & t-stat & Coefficient & t-stat & \\
\hline Intercept & $-14.402(12.709)$ & $1.133^{\mathrm{NS}}$ & $17.922(9.6988)$ & $1.848^{*}$ & \\
\hline Profit & $-4.09 \mathrm{e} 07(2.66 \mathrm{e}-6)$ & $0.153^{\mathrm{NS}}$ & $-8.35 e-7(3.08 \mathrm{e}-6)$ & $0.270^{\mathrm{NS}}$ & 8.986 \\
\hline TFP & $-9.6884(3.1161)$ & $3.109 * * *$ & $12.670(4.8857)$ & $2.593 * * *$ & 4.450 \\
\hline Age & $0.2900(0.1166)$ & $2.487 * *$ & $0.0803(0.0738)$ & $1.089^{\mathrm{NS}}$ & 6.539 \\
\hline Gender & $-2.2960(1.4251)$ & $1.611^{\mathrm{NS}}$ & $-1.0761(1.1497)$ & $0.936^{\mathrm{NS}}$ & 1.456 \\
\hline Marital status & $-2.0290(1.5481)$ & $1.311^{\mathrm{NS}}$ & $0.4317(0.9346)$ & $0.462^{\mathrm{NS}}$ & 1.350 \\
\hline Education & $0.5295(0.2261)$ & $2.341 * *$ & $0.2884(0.1236)$ & $2.334 * *$ & 3.843 \\
\hline Household size & $-0.8622(0.2957)$ & $2.916 * * *$ & $-0.3408(0.1703)$ & $2.002 * *$ & 1.449 \\
\hline Experience & $-0.0506(0.0779)$ & $0.650^{\mathrm{NS}}$ & $0.0511(0.0698)$ & $0.731^{\mathrm{NS}}$ & 5.749 \\
\hline Operational holding & $1.9168(0.7934)$ & $2.416 * *$ & $-0.9428(0.4639)$ & $2.032 * *$ & 7.001 \\
\hline Farm acquisition & $-1.4871(1.5415)$ & $0.964^{\mathrm{NS}}$ & $0.2594(1.1213)$ & $0.231^{\mathrm{NS}}$ & 1.324 \\
\hline Seed variety & $0.3117(1.7858)$ & $0.174^{\mathrm{NS}}$ & $-2.5719(1.8490)$ & $1.391^{\mathrm{NS}}$ & 1.215 \\
\hline Non-farm income & $3.5999(2.2174)$ & $1.623^{\mathrm{NS}}$ & $0.3376(1.3299)$ & $0.253^{\mathrm{NS}}$ & 2.437 \\
\hline Co-op. membership & $-0.6617(2.3031)$ & $0.287^{\mathrm{NS}}$ & $0.0367(1.7342)$ & $0.021^{\mathrm{NS}}$ & 1.304 \\
\hline Credit access & $0.8303(1.2491)$ & $0.664^{\mathrm{NS}}$ & $-0.1968(1.0857)$ & $0.181^{\mathrm{NS}}$ & 1.133 \\
\hline Extension visit & $0.1757(1.9933)$ & $0.088^{\mathrm{NS}}$ & $-0.1078(0.7936)$ & $0.135^{\mathrm{NS}}$ & 1.144 \\
\hline Annual income & $-0.1310(0.8523)$ & $0.153^{\mathrm{NS}}$ & $-1.2891(0.7834)$ & $1.646^{*}$ & 1.474 \\
\hline Yield & $0.0126(0.0062)$ & $2.01 * *$ & $-0.0205(0.0058)$ & $3.500 * * *$ & 3.677 \\
\hline
\end{tabular}

Source: Field survey, 2017

Note: $* * * * * * \&$ NS imply significant at $1 \%, 5 \%, 10 \%$ and non-significant, respectively.

Figures in ( ) and [ ] are standard error and probability level, respectively. Family labour is the base outcome

\section{Conclusion and Recommendations}

Based on the findings it was observed that exclusive use of either family labour or hired labour was affected by high TFP. Also, gender stereotype due to cultural factor affected women access and control to productive resources, thus hindered the use of paid labour for market-focused yam production. On the other hand, it can be inferred that high TFP that translates into high income turnover encouraged the use of combined labour. However, poor business going concern due to poor yield and low-income level affected farmers' decision to use combined labour that is hired labour supplemented. Therefore, for farmers to be able to harness combined labour efficiently for a good marketable surplus, thus a better wellbeing for farmers, farmers should be guided technically on how to achieve potential yield. In addition, imperfections in the market 
due to poor remunerative price which characterized seasonal cropping need to be addressed by stakeholders. viz. maintaining buffer stocks, thus enhancing farmers market turnover ratio. Also, the issue of gender inequality whereby gender stereotype denied women access and control to productive resources need to be tackled so as to achieve growth and development in the studied area.

\section{REFERENCES}

[1] J. D. Arikpo, et al., "Economic analysis of variables affecting the plantain (Musa sp) mono cropping system of production by small-scale farmers in central Cross River State, Nigeria," Journal of Agriculture, Forestry and Social Sciences, vol. 7, no. 2, pp. 75-87, 2009.

[2] N. E. Bassey, A. J. Akpaeti, and U. J. Udo, "Labour choice decisions among cassava crop farmers in Akwa Ibom State, Nigeria," International Journal of Food and Agricultural Economics, vol. 2, no. 3, pp. 145-156, 2014.

[3] L. Bervidova, "Labour productivity as a factor of sustainable economic development of the CR agriculture," The Agricultural Economics, vol. 48, no. 2, pp. 55-59, 2001.

[4] C. O. Anyiro, C. O. Emerole, C. K. Osondu, S. C. Udah, and S. E. Ugorji, "Labour-use efficiency by smallholder yam farmers in Abia State Nigeria: A labour-use requirementfrontier approach," International Journal of Food and Agricultural Economics, vol. 1, no. 1, pp. 151-163, 2013.

[5] K. A. Oluyole, O. A. Egbetokun, O. A. Oni, and E. O. Aigbekaen, "Technological changes and labour demand among cocoa farmers in Nigeria," World Journal of Agricultural Sciences, vol. 7, no. 5, pp. 638-641, 2011.

[6] C. Kadurumba, C. N. Uche, and M. S. Omole, "Labour-use efficiency by smallholder rice farmers in Ebonyi State Nigeria: A labour-use requirement frontier approach," International Journal of Agriculture and Rural Development, vol. 23, no. 1, pp. 4821-4829, 2020.

[7] I. A. Ajibefun, G. Ademola, and A. Obioma, "Investigation of factors influencing technical efficiency of small-holder crop farmer in Nigeria," CEPA Working Papers No. 10/96. Department of Economics, University of New England, 2000.

[8] National Population Commission (NPC), National population commission, Census Report, 2006.

[9] G. A. Churchill, "A paradigm for developing better measures of marketing constructs," Journal of Marketing Research, vol. 16, no. 1, pp. 64-73, 1979.

[10] R. Ullah, M. Rehman, M. Anjum, M. A. Kamran, K. Bakhsh, and A. Saboor, "Navigating farming risks by simultaneous diversification and credit through formal and informal communication channel," Pakistan Journal of Agricultural Research, vol. 29, no, 4, pp. 381-391, 2016.

[11] P. Idisi, S. E. Ebukiba, and L. Anthony, "Socio-economic factors influencing yam (Dioscoreaspp) production in Bwari Area Council, Abuja, Nigeria," Journal of Agriculture and Veterinary Science, vol. 12, no. 3-I, pp. 78-85, 2019.

[12] M. C. Nwike, T. O. OKoli, and C. O. A. Ugwumba, "Economics of water yam (Dioscoreaalata) Production in South Eastern Nigeria," Journal of Agriculture and Veterinary Science, vol. 10, no. 7-II, pp. 13-18, 2017.

[13] C. A. Otekhile and N. Verter, "The socioeconomic characteristics of rural farmers and their net income in Ojo and Badagry Local Government Areas of Lagos State, Nigeria," Acta Universitatis Agriculturae et Silviculturae Mendelianae Brunensis, Mendel University Press, vol. 65, no. 6, pp. 2037-2043, 2017. 